\title{
A Study of the Relationship between the Taste Sensitivity of Phenylthiocarbamide (PTC) and Blood Pressure (Random Sample from the Students of Qurna College/Basrah-Iraq)*
}

\author{
Hasna Amir Mohaus', Asaad Y. Ayied ${ }^{2}$ \\ ${ }^{1}$ Biology Department, College of Education in Qurna, University of Basrah, Basrah, Iraq \\ ${ }^{2}$ Animal Production Department, College of Agriculture, University of Basrah, Basrah, Iraq \\ Email: asaad.yheia@gmail.com
}

How to cite this paper: Mohaus, H.A. and Ayied, A.Y. (2018) A Study of the Relationship between the Taste Sensitivity of Phenylthiocarbamide (PTC) and Blood Pressure (Random Sample from the Students of Qurna College/Basrah-Iraq)*. Journal of Biosciences and Medicines, 6, 1-12.

https://doi.org/10.4236/jbm.2018.611001

Received: September 9, 2018

Accepted: November 13, 2018

Published: November 16, 2018

Copyright $\odot 2018$ by authors and Scientific Research Publishing Inc. This work is licensed under the Creative Commons Attribution International License (CC BY 4.0).

http://creativecommons.org/licenses/by/4.0/

(c) (i) Open Access

\begin{abstract}
The present study aimed to detect the relationship between taste sensitivity of phenylthiocarbamide (PTC) and pressure (systolic and diastolic) among a group of 138 individuals of both sexes (64 males and 74 females), representing a random sample of students and some professors of, aged (20 - 50) years. The study also included the relationship between eating salted foods and their effect on pressure among males and females of tasters and non-tasters of (PTC) substance. The results showed an increase in the proportion of the phenotypic style of tasters compared to non-tasters among males (75\%, 25\%) and females $(77.03 \%, 22.97 \%)$ respectively. The average of systolic pressure was (117.91 mm/Hg, $107.06 \mathrm{~mm} / \mathrm{Hg})$ and diastolic $(78.22 \mathrm{~mm} / \mathrm{Hg}, 68.71 \mathrm{~mm} / \mathrm{Hg})$ among tasters and on-tasters for both sexes respectively. The results showed significant differences in systolic pressure among non-tasters female compared to their counterpart tasters $\left[X^{2}(\mathrm{DF}=1) 5.783, \mathrm{P} \leq 0.05\right]$. Such an effect doesn't appear among males. The results showed an increase of non-tasters (66.58\%) among those with abnormal blood pressure and $(68.42 \%)$ of those who consumed salted foods.
\end{abstract}

\section{Keywords}

Phenylthiocarbamide (PTC), Taste, Blood Pressure

\section{Introduction}

Diseases of blood pressure are complex diseases. They are a result of genetic or

${ }^{\star}$ A study of the relationship between the taste sensitivity of phenylthiocarbamide. 
epigenetic and environmental factors (lifestyle, physical activities, food habits), consumption of salty food represents the main environmental factor [1]. It was found that consumption of high level of salty food associated with hypertension and an increase in the danger of heart disease and stroke [2] [3] [4] [5]. As well as excessive obesity, consumption of high level of fat in the food is another factor to increase the rate of hypertension [5].

Therapeutics with the assistance of food regulation becomes one of the recent features to prevent many diseases especially chronic ones [6]. Taste is one of the most important factors to determine the amount and quality of food [7]. There is increasing interest day by day in the study of taste and its impact on the nutritional behavior of individuals [8] [9]. It was found that the importance of taste is not limited to its role before eating, but found that taste cells have other roles after eating [10].

The ability to taste phenylthiocarbamide PTC (containing N-C=S, which is among the many chemicals that possess the same bitter taste and biological efficacy as 6-n-Propylthiouracil) is an important genetic trait that can play a role in the variation of individuals in the behavior of food to taste sweet and salty substances in addition to a group of vegefoods, fruits and fatty foods [9] [11] [12]. Perhaps the most important is the vegefoods belonging to the Cruciferous family of medical importance in the fight against a number of diseases due to its rich contents in a number of compounds with biological effectiveness and antioxidants [13] [14].

Phenotypically PTC is a simple Mendelian trait under the control of one somatic gene with complete dominance [15] [16]. At the molecular level, it was found that the inheritance of this character belongs to the presence of a major gene site controlling the observed variation in the sensitivity of the taste of this substance situated on the seventh chromosome VII (7q34-35) called tas2r38 [17]. It is one of the types of cellular receptors to taste bitter substances. The percentage of those who taste this substance is very different among Asian-American, African and European [13] [18] [19] [20]. The classification of individuals to tasters and non-tasters is generally associated with their sensitivity of taste for all types of taste: salty, sour and sweet [8] [21] [22]. The taste of salt, especially $\mathrm{NaCl}$, is done through epithelial $\mathrm{Na}$ channels (EnaC) and these channels in the kidney play an important role in maintaining electrolytes stability in the whole body [23] [24].

Genetic modifications that affect the regulatory mechanism that leads to high blood pressure associated with the sensitivity of tasting salts are still unclear [24]. Understanding the role of genes in regulating blood pressure in the kidney may lead to the development of antihypertensive therapies build on individual's genetic makeup [24]. Many factors, including hormones such as insulin, may play a role in regulating taste in general and taste of table salt specifically through sodium ion channels in taste receptor cells (TCR) [25]. The individuals were divided into three phenotypes for tasting of PTC substance depending on their 
sensitivity to taste different concentrations of sodium chloride $\mathrm{NaCl}$ in addition to the substance PTC belonging to three genotypes which are supertaster (ST), medium taster (MT) with a genotypes of TT and Tt respectively and non-taster of recessive tt genotype [26] [27] [28]. It was found that the sensitivity of tasting the table salt was less among those infected with high pressure [3].

We assumed that the non-tasters of PTC who are also less sensitive to the taste of salts especially $\mathrm{NaCl}$ may encourage the consumption of more salt which may lead to the possibility of high pressure disease compared to the taster and therefore we seen in present study to detect the accuracy of this conclusion by first, knowing the proportions of the tasters and non-tasters of PTC among a random sample of the students of Qurna Education College/University of Basrah; diastolic and systolic pressure was observed and recorded to detect any differences between them. In addition to measuring the BMI (as a measure of obesity), to determine the extent of eating salted food on blood pressure, we present a questionnaire. Note that this study is conducted for the first time.

\section{Materials and Methods}

\subsection{Preparation of Gradually Solutions and PTC Sensitivity Test Papers}

A $0.13 \mathrm{~g}$ of PTC was weighed with a sensitive digital balance, and then was dissolved in $100 \mathrm{ml}$ of distilled water to prepare solution No.1, which represents the highest concentration, and attended a series of gradual dilution [16]. A boiling distill water was considered as control. Ashly [29] method to prepare PTC test paper was followed (Table 1).

Table 1. Concentration of taste testing series of PTC solutions used in the present study.

\begin{tabular}{cc}
\hline Solution number & PTC $(\mathrm{mg} / 100 \mathrm{ml})$ \\
\hline $\mathbf{1}$ & 130 \\
$\mathbf{3}$ & 65 \\
$\mathbf{4}$ & 32.5 \\
$\mathbf{5}$ & 16.25 \\
$\mathbf{6}$ & 8.125 \\
$\mathbf{7}$ & 4.0625 \\
$\mathbf{8}$ & 2.0313 \\
$\mathbf{9}$ & 1.0156 \\
10 & 0.5078 \\
11 & 0.2539 \\
12 & 0.127 \\
13 & 0.0635 \\
& 0.0317
\end{tabular}




\subsection{PTC Sensitivity Test}

Individuals were asked to wash their mouths with fresh water to avoid any bitter or other taste. Then, they started to taste filter paper (control) followed by PTC test paper with grade 13 (lowest PTC concentration) towards the highest concentration (sol. No.1 PTC concentration) till they feel the bitter taste when the degree of PTC sensitive test was recorded, each person repeated this practice three times. The grade recorded when each person had the same grade twice or more times.

\subsection{Critical PTC Test Value (Threshold) and Tasting of Salting Foods}

PTC critical test value was recorded for each individual. Phenotypic classes of PTC test trait were determined depending on critical binomial distribution. The anti-mode point was used to the classified individual as tasters and non-tasters [30]. In the case of eating salted foods, the questionnaire method was used to identify them.

\subsection{Biometric Measurements}

Systolic (SBP) and diastolic (DBP) pressures were measured for each individual using the mercury scale. High blood pressure was determined as $140 \mathrm{mmHg}$ SBP or higher or diastolic pressure (DBP) $90 \mathrm{mmHg}$ or higher [31]. More or less than normal value were consider as an abnormal of blood pressure The weight, length of each person were measured and the biomass index (BMI) was calculated as weight, $\mathrm{kg} / \mathrm{height}, \mathrm{m}^{2}$.

\subsection{Statistical Analysis}

The frequency of each PTC sensitive phenotypic and genotypic classes was calculated as a percent of each class to the total number of tested individuals. Chi-square test was used to determine significant differences between different classes and groups. 0.05 was assigned as a significant level. Statistical packages IBM SPSS (version 22, 2013) was used for all statistical analysis.

\section{Results}

PTC taste threshold No. 3 represented the anti-mode of the binomial distribution of PTC taster and non-taster curve (Figure 1).

Table 2 shows the mean of SBP, DBP, and BMI of males' taster and non-taster. Tasters and non-tasters percentages were $75 \%$ and $25 \%$ respectively. Mean of SBP and DBP among males tasters were 117.91 and $78.22 \mathrm{~mm} / \mathrm{Hg}$ respectively, those for non-tasters were 107.06 and $68.71 \mathrm{~mm} / \mathrm{Hg}$ respectively. Mean of BMI of male tasters and non-tasters were 24.70 and $26.86 \mathrm{~kg} / \mathrm{m}^{2}$ respectively. Statistical analysis did not reveal significant differences between males' tasters and non-tasters for both blood pressure and BMI index.

In the case of females, the distribution of DBP appeared to be different between 


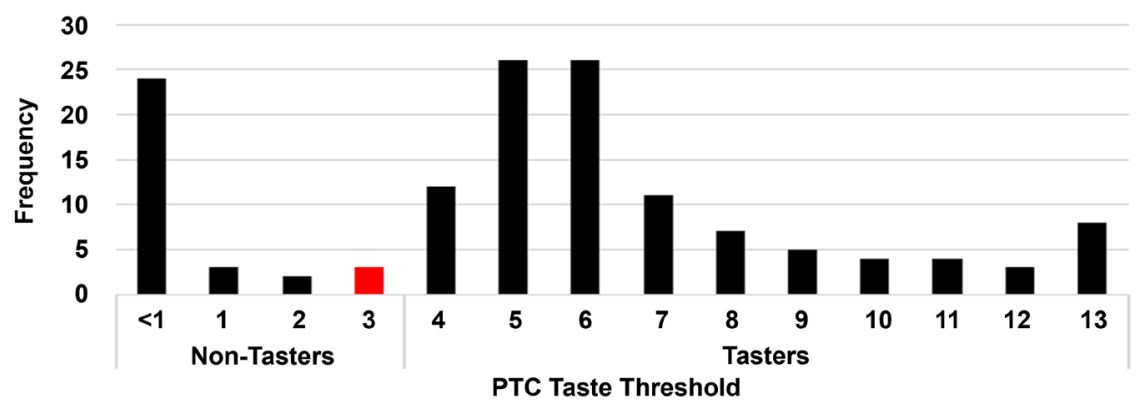

Figure 1. PTC taste threshold distribution.

Table 2. Mean of SBP, DBP, and BMI of males' taster and non-tasters.

\begin{tabular}{cccccc}
\hline phenotype & No. & Percent $\%$ & SBP mm/Hg & DBP mm/Hg & BMI Kg/m ${ }^{2}$ \\
\hline Tasters & 48 & 72 & $117.91^{\mathrm{a}}$ & $72.21^{\mathrm{a}}$ & $24.70^{\mathrm{a}}$ \\
Non-Tasters & 16 & 25 & $107.06^{\mathrm{a}}$ & $68.71^{\mathrm{a}}$ & $26.86^{\mathrm{a}}$ \\
Total & 64 & 100 & 112.48 & 73.46 & 25.78 \\
\hline
\end{tabular}

SBP: Systolic Blood Pressure, DBP: Diastolic Blood Pressure, BMI: Body Mass Index, ${ }^{a}$ Means of each trait with same subscripts are not significantly differing.

tasters and non-tasters Table 3. It was noticed a significant differences between the two groups $\left[X^{2}(\mathrm{DF}=1)=5.78, \mathrm{P} \leq 0.05\right]$. The value of BMI between females' tasters and non-tasters were nearly similar 22.84 and $22.801 \mathrm{~kg} / \mathrm{m}^{2}$ respectively.

Overall mean of SBP and DBP of tasters (males and females) were 114.84 and $78.21 \mathrm{~mm} / \mathrm{Hg}$, non-tasters (males and females) were 115.12 and $79.22 \mathrm{~mm} / \mathrm{Hg}$ respectively (Table 4). As well as, overall mean of BMI for tasters' males and females and non-tasters were 23.77 and $24.83 \mathrm{~kg} / \mathrm{m}^{2}$ respectively. Both blood pressure and BMI reveal no significant differences $\left[X^{2}(\mathrm{DF}=1)=2.900, \mathrm{P}>\right.$ $0.05 ; X^{2}(\mathrm{DF}=1)=2.929, \mathrm{P}>0.05$ respectively].

Table 5 shows the abnormal blood pressure individuals among tasters and non-tasters. Male tasters and non-tasters percentages were $30.00 \%$ and $70.00 \%$ respectively. Those of females were $36.80 \%$ and $63.15 \%$. The differences were highly significant at 0.05 and $0.01\left[X^{2}(\mathrm{DF}=1)=25.4, \mathrm{P} \leq 0.05\right]$.

There was a significant $(\mathrm{P}<0.05)$ association between individual consumed salty food with abnormal blood pressure, especially in males (Table 6). Individuals with abnormal blood pressure and consumed salty food recorded $68.42 \%$, other don't consume salty foods $31.58 \%$ from the total number of abnormal blood pressure individuals (total number was 19).

\section{Discussion}

Our results indicate that there is a high percentage of people with abnormal blood pressures among those who are not tasters and those prefer salted foods, which are more likely to be infected The results also indicate that there is a gender impact in the incidence of abnormal blood pressures, as it rises among 
Table 3. Mean of SBP, DBP, and BMI of females' tasters and non-tasters.

\begin{tabular}{cccccc}
\hline Phenotype & No. & Percent \% & SBP mm/Hg & DBP mm/Hg & BMI kg/m ${ }^{2}$ \\
\hline Tasters & 57 & 77.03 & $111.76^{\mathrm{a}}$ & $78.21^{\mathrm{b}}$ & $22.84^{\mathrm{a}}$ \\
Non-tasters & 17 & 22.97 & $123.18^{\mathrm{a}}$ & $89.12^{\mathrm{a}}$ & $22.80^{\mathrm{a}}$ \\
Total & 74 & 100 & 117.47 & 80.72 & 22.82 \\
\hline
\end{tabular}

SBP: Systolic Blood Pressure, DBP: Diastolic Blood Pressure, BMI: Body Mass Index, ${ }^{\mathrm{a}, \mathrm{b}}$ Means with different subscripts of each trait differ significantly at 0.05 level.

Table 4. Mean of SBP, DBP, and BMI of males and females tasters and non-tasters.

\begin{tabular}{cccccc}
\hline Phenotype & No. & Percent \% & SBP mm/Hg & DBP mm/Hg & BMI kg/m ${ }^{2}$ \\
\hline Tasters & 105 & 76.08 & $114.84^{\mathrm{a}}$ & $78.21^{\mathrm{a}}$ & $23.77^{\mathrm{a}}$ \\
Non-tasters & 33 & 23.92 & $115.12^{\mathrm{a}}$ & $79.22^{\mathrm{a}}$ & $24.83^{\mathrm{a}}$ \\
Total & 138 & 100 & 114.98 & 78.45 & 24.30 \\
\hline
\end{tabular}

BP: Systolic Blood Pressure, DBP: Diastolic Blood Pressure, BMI: Body Mass Index, ${ }^{\mathrm{a} M e a n s}$ of each trait with same subscripts are not significantly differing.

Table 5. Number and percent of tasters and non-tasters with abnormal blood pressure.

\begin{tabular}{cccccc}
\hline & & & \multicolumn{2}{c}{ Tasters } & \multicolumn{2}{c}{ Non-tasters } \\
\cline { 3 - 6 } Gender & Total No. & No. & Percent $\%$ & No. & Percent \% \\
\hline Males & 10 & 3 & $30.00^{\mathrm{b}}$ & 7 & $70.00^{\mathrm{a}}$ \\
Females & 19 & 7 & $36.80^{\mathrm{b}}$ & 12 & $63.15^{\mathrm{a}}$ \\
Total & 29 & 10 & 33.40 & 19 & 66.58 \\
\hline
\end{tabular}

${ }^{\mathrm{a} b} \mathrm{M}$ Means with different subscripts in each row differ significantly at 0.05 .

Table 6. Association between salty food consumption and abnormal blood pressure (males and females).

\begin{tabular}{|c|c|c|c|c|c|}
\hline \multirow{3}{*}{$\begin{array}{l}\text { Consuming salty } \\
\text { food }\end{array}$} & \multicolumn{5}{|c|}{ Abnormal blood pressures } \\
\hline & \multirow{2}{*}{ Total No. (\%) } & \multicolumn{2}{|c|}{ Males } & \multicolumn{2}{|c|}{ Females } \\
\hline & & No. & Percent \% & No. & Percent \% \\
\hline Yes & $13(68.42)$ & 9 & $69.23^{\mathrm{a}}$ & 4 & $30.76^{\mathrm{b}}$ \\
\hline No & $6(31.58)$ & 2 & $33.33^{\mathrm{b}}$ & 4 & $66.66^{\mathrm{a}}$ \\
\hline Total & $19(100)$ & 11 & 57.89 & 8 & 42.11 \\
\hline
\end{tabular}

${ }^{\mathrm{a}, \mathrm{b}}$ Percentages with different subscripts each columns different significantly at 0.05 .

non-tasters women more than males. The BMI scale did not have a role in the studied sample. This may be due to the fact that the sample studied is mostly young. Hypertension is a major cause of heart attack, which is the leading cause of death in the world, according to the World Health Organization [31] [32].

The variation in taste at the individual, ethnic or groups' level may play a role in the variability of the diseases [33] [34] [35]. The taste is influenced by many factors, perhaps the most important age and sex, as women are more accurate in 
the taste of men [26] [36] [37]. It has been found that non-tasters of PTC is more confused in the accuracy of taste compared to the tasters and this may lead to the infection of some diseases at sometimes [38]. Also, both alleles of the taster or non-taster of the PTC can contribute to the infection and the resistance of some diseases being the non-taster are the most susceptible [39] [40]. Timpson et al. [21] pointed to the possibility of non-taster infected by heart disease and stroke more than tasters, but the results did not confirm this.

Bitter substances play an important role in human life as a medicine in addition to its role as food [14]. These substances and their receptors can also play a role in food digestion and metabolism [41] and homeostasis of the human body [11] [42] [43]. The presence of taste receptors for bitter substances in extra oral cavity suggest that they may play important and varied roles in the rest of the body depending on where they are located; as in the respiratory tract [44] [45], along gastrointestinal [46] [47], cardiac tissue [48], thyroid [49], blood cell [50] and the lung [51]. The genetic expression of the bitter taste receptors in renal epithelial cells indicates that these receptors may play roles in evolution and overall functions of kidney [52].

High blood pressure is one of the most complicated diseases and there are many common causes of this disease. Eating or consuming salts is a major cause, in addition to many other internal factors, obesity is one of the main causes of high blood pressure [53]. Research results varied in relation to BMI and PTC taste, some support and others denied [34] [54] [55] PTC non tasters women may have a different mechanism of Weight regulation [56].

The genetic manipulation that affects the regulatory mechanism leads to high blood pressure associated with the sensitivity of salty taste are still unclear [24]. The discovery of the presence of the bitter taste receptors in the epithelial cells of the kidney [52] is a clear indication of the comprehensiveness and diversity of its functions in the regulation of many activities of the body, including the kidney and its functions. The most important of which is the regulation of ionic saline balance. The individuals variation of genetically modified in the forms of these receptors may be reflected negatively or positively in maintaining this balance.

Many researchers have suggested that there may be physiological differences between tasters and non-tasters, as hormones levels [23] [57]. Hormones also play a role in regulating pressure [23] [25]. The life of the patient with hypertension depends mainly on the quality of the food he is eating and that the sudden rise (specifically of salts) or the sudden drop causes a heart stroke, as the increase in salt intake or lack of excretion leads to a rise in the bloodstream, and the average reduction of salt can significantly reduce stress in healthy or high blood pressure people [23] [25] [58] [59] and thus heart attack [60].

The importance of taste in human life is illustrated by the effect of taste on its behavior in the choice of food and hence on its dietary habits and the identification of food or toxins [61] [62]. The variation in the taste ratio of PTC is associated with the variation in food selection and is probably associated with 
food-related diseases among modern human societies [13] [63]. PTC tasting polymorphism could be a useful biomarker in health and disease [9] [47] [64]. As indicated by many recent researches, which proved that eating a variety of fresh foods from fruits and vegetables can be sufficient to treat many chronic diseases [65]. Therefore, the regulation of food and lifestyle may have an effect in the treatment of hypertension [66], so this trait could be one of these strategies.

\section{Conclusion}

People that suffer from high blood pressure were mostly non-tasters, $70 \%$ in males and $63.15 \%$ in females. As well as non-tasters, females as a whole showed higher DBP than taster females. There is association between salty food and blood pressure in males only.

\section{Conflicts of Interest}

The authors declare no conflicts of interest regarding the publication of this paper.

\section{References}

[1] Yang, J., Jose, P.A. and Chunyu, Z. (2017) Gastrointestinal-Renal Axis: Role in the Regulation of Blood Pressure. Journal of the American Heart Association, 6, e005536. https://doi.org/10.1161/JAHA.117.005536

[2] Mattes, R.D. (1997) The Taste for Salt in Humans. The American Journal of Clinical Nutrition, 65, 692S-697S. https://doi.org/10.1093/ajcn/65.2.692S

[3] Michikawa, T., Nishiwaki, Y., Okamura, T., Asakura, K., Nakano, M. and Takebayashi, T. (2009) The Taste of Salt Measured by a Simple Test and Blood Pressure in Japanese Women and Men. Hypertension Research, 32, 399-403.

https://doi.org/10.1038/hr.2009.31

[4] Forouzanfar, M. (2017) Global Burden of Hypertension and Systolic Blood Pressure of at Least 110 to $115 \mathrm{~mm} \mathrm{Hg}, 1990-2015$. JAMA, 317, 165-182.

https://doi.org/10.1001/jama.2016.19043

[5] Pesantes, A.M., Diez, C.F. and Ortiz, A.B. (2017) Taste, Salt Consumption and Local Explanations around Hypertension in a Rural Population in Northern Peru. $\mathrm{Nu}^{-}$ trients, 698, 1-13. https://doi.org/10.3390/nu9070698

[6] Cassady, B.A. and Mattes, R.D. (2010) Taste Sensation: Influences on Human Ingestive Behaviors. In: Struble, M.B., Ed., Nutrition Guide for Physicians, Humana Press, City, NJ, 159-168. https://doi.org/10.1007/978-1-60327-431-9_14

[7] Franz, M.J. (2010) Nutrition Therapy Effectiveness for the Treatment for Type 1 and Type 2 Diabetes: Prioritizing Recommendations Based on Evidence from $\mathrm{Nu}$ trition and Health: Nutrition Guide for Physicians. In: Wilson, T., et al., Eds., Humana Press, a Part of Springer Science Business Media, LLC 2010.

[8] Turner-McGrievy, G.F., Tate, D. and Moore, D. (2013) Taking the Bitter with the Sweet: Relationship of Super Tasting and Sweet Preference with Metabolic Syndrome and Dietary Intake. Journal of Food Science, 78, S336-S342. https://doi.org/10.1111/1750-3841.12008

[9] Tepper, B.J.I.D., Melis, M., Koelliker, Y., Gasparini, P., Ahijevych, K.L. and Barbarossa, I.T. (2017) Factors Influencing the Phenotypic Characterization of the Oral Marker, PROP. Nutrients, 9, 1275. 
[10] Egan, J.M. and Margolskee, R.F. (2008) Taste Cells of the Gut and Gastrointestinal Chemosensation. Molecular Interventions, 8, 78-81. https://doi.org/10.1124/mi.8.2.5

[11] Dotson, C.D., Shaw, H.L., Mitchell, B.D., Munger, S.D. and Steinle, N.I. (2010) Variation in the Gene TAS2R38 Is Associated with the Eating Behavior Disinhibition in Old Order Amish Women. Appetite, 54, 93-99. https://doi.org/10.1016/j.appet.2009.09.011

[12] Dinehart, M.E., Hayes, J.E., Bartoshuk, L.M., Lanier, S.L. and Duffy, V.B. (2006) Bitter Taste Markers Explain Variability in Vegetable Sweetness, Bitterness, and Intake. Physiology \& Behavior, 87, 304-313. https://doi.org/10.1016/j.physbeh.2005.10.018

[13] Wooding, S., Kima, U.K., Bamshad, M.J., Larsen, J., Jord, L. and Drayan, D. (2013) Natural Selection and Molecular Evolution in PTC, Bitter-Taste Receptor Gene. $A J H G$, 74, 637-646. https://doi.org/10.1086/383092

[14] Newcomb, R.D., Xia, M.B. and Reed, D.R. (2012) Heritable Differences in Chemosensory Ability among Humans. Flavor, 1, 9. https://doi.org/10.1186/2044-7248-1-9

[15] Fox, A.L. (1932) The Relationship between Chemical Constitution and Taste. Proceedings of National Academy of Sciences of USA, 18, 115-120. https://doi.org/10.1073/pnas.18.1.115

[16] Harris, H. and Kalmus, H. (1949) The Measurement of Taste Sensitivity to (PTC). Annals of Eugenics, 15, 24-31. https://doi.org/10.1111/j.1469-1809.1949.tb02419.x

[17] Kim, U.K., Jorgenson, E., Coon, H., Leppert, M., Risch, N. and Drayna, D. (2003) Positional Cloning of the Human Quantitative Trait Locus Underlying Taste Sensitivity to Phenylthiocarbamide. Science, 299, 1221-1225. https://doi.org/10.1126/science.1080190

[18] Guo, S.W. and Reed, R.D. (2001) The Genetics of Phenylthiocarbamide Perception. Annals of Human Genetics, 28, 111-142.

[19] Timpson, N.J., Heron, J. and Day, I.N. (2007) Refining Associations between TAS2R38 Diplotypes and the 6-n-propylthiouracil (PROP) Taste Test: Findings from the Avon Longitudinal Study of Parents and Children. BMC Genetics, 8, 51. https://doi.org/10.1186/1471-2156-8-51

[20] Campbell, M.C., Ranciaro, A., Froment, A., Hirbo, J., Omar, S., Bodo, J., et al. (2012) Evolution of Functionally Diverse Alleles Associated with PTC Bitter Taste Sensitivity in Africa. Molecular Biology and Evolution, 29, 1141-1153. https://doi.org/10.1093/molbev/msr293

[21] Timpson, N.J., Chriten, M., Lawlor, D.A., Gaunt, T.R., Day, I.N. and Ebrahim, S. (2005) TAS2R38 (Phenylthiocarbamide) Haplotypes, Coronary Heart Disease Traits, and Eating Behavior in the British Women's Heart and Health Study. The American Journal of Clinical Nutrition, 81, 1005-1011.

https://doi.org/10.1093/ajcn/81.5.1005

[22] Doty, R., Shah, M. and Bromley, S. (2008) Drug-Induced Taste Disorders. Drug Safety, 31, 199-215. https://doi.org/10.2165/00002018-200831030-00002

[23] Loper, H.B., La Sala, M., Dotson, C. and Steinle, N. (2015) Taste Perception, Associated Hormonal Modulation, and Nutrient Intake. Nutrition Reviews, 73, 83-91. https://doi.org/10.1093/nutrit/nuu009

[24] Jose, P.A., Yang, Z., Zeng, C. and Felder, R.A. (2016) The Importance of the Gastrorenal Axis in the Control of Body Sodium Homeostasis. Experimental Physiology, 101, 465-470. https://doi.org/10.1113/EP085286 
[25] Baquero, F.A. and Gilbertson, T.A. (2011) Insulin Activates Epithelial Sodium Channel (ENaC) via Phosphoinositide 3-Kinase in Mammalian Taste Receptor Cells. American Journal of Physiology-Cell Physiology, 300, C860-C871. https://doi.org/10.1152/ajpcell.00318.2010

[26] Bartoshuk, L.M., Duffy, V.B. and Miller, I.J. (1994) PTC/PROP Tasting, Anatomy, Psychophysics and Sex Effects. Physiology \& Behavior, 56, 1165-1171. https://doi.org/10.1016/0031-9384(94)90361-1

[27] Tepper, B.J. and Nurse, R.J. (1997) Fat Perception Is Related to PROP Taster Status. Physiology \& Behavior, 61, 949-954. https://doi.org/10.1016/S0031-9384(96)00608-7

[28] Drewnowski, A., Henderson, S.A. and Barratt-fornell, A. (2011) Genetic Taste Makers and Food References. American Society for Pharmacology and Experimental Therapeutics, 29, 535-538.

[29] Ashly, M.M.F. (1960) An Introduction to Physical Anthropology. 3rd Edition, Charles C. Thomas.

[30] Omari, Y.I. (1986) Taste Deficiency of Phenylthiourea in Jordanians Population. Journal of Biological Sciences Research, 17, 253-265.

[31] NCD Risk Factor Collaboration (2017) Worldwide Trends in Blood Pressure from 1975 to 2015: A Pooled Analysis of 1479 Population-Based Measurement Studies with 19.1 Million Participants. The Lancet, 389, 37-55.

https://doi.org/10.1016/S0140-6736(16)31919-5

[32] Whelton, P.K., Carey, R.M., Wilbert, S.A., Donald, E.C., Karen, J.C., et al. (2017) ACC/AHA 2017 High Blood Pressure Clinical Practice Guideline. Guideline for the Prevention, Detection, Evaluation, and Management of High Blood Pressure in Adults.

[33] Zhao, L., Stamler, J., Yan, L.L., Zhou, B., Wu, Y., Liu, K., Daviglus, M.L., Dennis, B.H., Elliott, P., Ueshima, H., Yang, J., Zhu, L. and Guo, D. (2004) Blood Pressure Differences between Northern and Southern Chinese: The Role of Dietary Factors: The International Study on Macronutrients and Blood Pressure. Hypertension, 43, 1332-1337. https://doi.org/10.1161/01.HYP.0000128243.06502.bc

[34] Choi, S.E. (2014) Racial Differences between African Americans and Asian Americans in the Effect of 6-n-propylthiouracil Taste Intensity and Food Liking on Body Mass Index. Journal of the Academy of Nutrition and Dietetics, 114, 938-944. https://doi.org/10.1016/j.jand.2013.11.015

[35] Leong, C.S., Forde, C.G., Teysl and Henry, C.J. (2018) Taste Perception and Diet in People of Chinese Ancestry. Asia Pacific Journal of Clinical Nutrition, 27, 478-486.

[36] Whissell-Buechy, D. (1990) Effects of Age and Sex on Taste Sensitivity to Phenylthiocarbamide (PTC) in the Berkeley Guidance Sample. Chemical Senses, 15, 39-57. https://doi.org/10.1093/chemse/15.1.39

[37] Doty, R.L. and DeFonte, T.P. (2016) Relationship of Phenylthiocarbamide (PTC) Taster Status to Olfactory and Gustatory Function in Patients with Chemosensory Disturbances. Chemical Senses, 41, 685-696. https://doi.org/10.1093/chemse/bjw070

[38] Doty, R.L., Chen, J.H. and Overend, J. (2017) Taste Quality Confusions: Influences of Age, Smoking, PTC Taster Status, and Other Subject Characteristics. Perception, 46, 257-267. https://doi.org/10.1177/0301006616685577

[39] Dzaman, K., Zagor, M., Sarnwaska, F., Krzeski, A. and Kanor, I. (2016) The Correlation of TAS2R38 Gene Variants with Higher Risk for Chronic Rhinosinusitis in Polish Patients. Otolaryngologia Polska, 70, 13-18. 
https://doi.org/10.5604/00306657.1209438

[40] Yamak, M., Saito, H., Isono, K., Goto, T., et al. (2017) Genotyping Analysis of Bitter-Taste Receptor Genes TAS2R38 and TAS2R46 in Japanese Patients with Gastrointestinal Cancers. Journal of Nutritional Science and Vitaminology (Tokyo), 63, 148-154. https://doi.org/10.3177/jnsv.63.148

[41] Kojima, I. and Nakagawa, Y. (2011) The Role of the Sweet Taste Receptor in Enteroendocrine Cells and Pancreatic $\beta$-Cells. Diabetes \& Metabolism Journal, 35, 451-457. https://doi.org/10.4093/dmj.2011.35.5.451

[42] Dotson, C.D., Zhang, L., Xu, H., Shin, Y.K., Vigues, S., Ott, S.H., et al. (2008) Bitter Taste Receptors Influence Glucose Homeostasis. PLoS ONE, 3, e3974. https://doi.org/10.1371/journal.pone.0003974

[43] Campa, D., De Rango, F., Carrai, M., Crocco, P., Montesanto, A. and Canzian, F. (2012) Bitter Taste Receptor Polymorphisms and Human Aging. PLoS ONE, 7, e45232. https://doi.org/10.1371/journal.pone.0045232

[44] Grassin-Delyle, S., Abrial, C., Brollo, M., Naline, E. and Devillier, P. (2014) Taste Receptors in the Lungs: Interesting or Anecdotal? Revue de Pneumologie Clinique, 70, 148-155. https://doi.org/10.1016/j.pneumo.2013.11.008

[45] Lee, R.J. and Cohen, N.A. (2013) The Emerging Role of the Bitter Taste Receptor T2R38 in Upper Respiratory Infection and Chronic Rhinosinusitis. American Journal of Rhinology \& Allergy, 27, 283-286. https://doi.org/10.2500/ajra.2013.27.3911

[46] Rozengurt, E. (2006) Taste Receptors in the Gastrointestinal Tract. I. Bitter Taste Receptors and Alpha-Gustducin in the Mammalian Gut. American Journal of Physiology-Gastrointestinal and Liver Physiology, 291, 171-177. https://doi.org/10.1152/ajpgi.00073.2006

[47] Depoortere, I. (2014) Taste Receptors of the Gut: Emerging Roles in Health and Disease. Gut, 63, 179-190. https://doi.org/10.1136/gutjnl-2013-305112

[48] Foster, S.R., Blank, K., See Hoe, L.E., Behrens, M., Meyerhof, W., Peart, J.N. and Thomas, W.G. (2014) Bitter Taste Receptor Agonists Elicit G-Protein-Dependent Negative Inotropy in the Murine Heart. The FASEB Journal, 28, 4497-4508. https://doi.org/10.1096/fj.14-256305

[49] Clark, A.A., Dotson, C.D., Elson, A.E.T., Voigt, A., Boehm, U., Meyerhof, W., Steinle, N.I. and Munger, S.D. (2015) TAS2R Bitter Taste Receptors Regulate Thyroid Function. The FASEB Journal, 29, 164-172. https://doi.org/10.1096/fj.14-262246

[50] Maurer, S., Wabnitz, G.H., Kahle, N.A., Stegmaier, S., Prior, B., Giese, T., Gaida, M.M., Samstag, Y. and Hänsch, G.M. (2015) Tasting Pseudomonas aeruginosa Biofilms: Human Neutrophils Express the Bitter Receptor T2R38 as Sensor for the Quorum Sensing Molecule N-(3-Oxododecanoyl)-1-Homoserine Lactone. Frontiers in Immunology, 24, 369.

[51] Roland, W.S.U. (2014) Intrinsic Bitterness of Flavonoids and Isoflavonoids and Masking of Their Taste Activity. PhD Thesis, Wageningen University, Wageningen.

[52] Liang, J., Chen, F., Gu, F., Liu, X.F. and Du, D. (2017) Expression and Functional Activity of Bitter Taste Receptors in Primary Renal Tubular Epithelial Cells and M-1 Cells. Molecular and Cellular Biochemistry, 428, 193-202. https://doi.org/10.1007/s11010-016-2929-1

[53] Mojet, J., Christ-Hazelhof, E. and Heidema, J. (2001) Taste Perception with Age: Generic or Specific Losses in Threshold Sensitivity to the Five Basic Tastes. Chemical Senses, 26, 845-860. https://doi.org/10.1093/chemse/26.7.845 
[54] Deshaware, S. and Singhal, R. (2017) Genetic Variation in Bitter Taste Receptor Gene TAS2R38, PROP Taster Status and Their Association with Body Mass Index and Food Preferences in Indian Population. Gene, 627, 363-368. https://doi.org/10.1016/j.gene.2017.06.047

[55] Tepper, B.J., Banni, S., Melis, M., Crnjar, R. and Barbarossa, I.T. (2014) Genetic Sensitivity to the Bitter Taste of 6-n-Propylthiouracil (PROP) and Its Association with Physiological Mechanisms Controlling Body Mass Index (BMI). Nutrients, 6, 3363-3381. https://doi.org/10.3390/nu6093363

[56] Burgess, B., Raynor, H.A. and Tepper, B.J. (2017) PROP Non-Taster Women Lose More Weight Following a Low-Carbohydrate versus a Low-Fat Diet in a Randomized Controlled Trial. Obesity, 25, 1682-1690. https://doi.org/10.1002/oby.21951

[57] Wang, R., van Keeken, N.M., Siddiqui, S., Dijksman, L.M., Maudsley, S., Derval, D., van Dam, P.S. and Martin, B. (2014) Higher TNF- $\alpha$, IGF-1, and Leptin Levels Are Found in Tasters than Non-Tasters. Frontiers in Endocrinology (Lausanne), 5, 125. https://doi.org/10.3389/fendo.2014.00125

[58] He, F.J., Li, J. and Macgregor, G.A. (2013) Effect of Longer-Term Modest Salt Reduction on Blood Pressure: Cochrane Systematic Review and Meta-Analysis of Randomized Trials. BMJ, 346, f1325. https://doi.org/10.1136/bmj.f1325

[59] Graudal, N.A., Hubeck-Graudal, T. and Jurgens, G. (2011) Effects of Low Sodium Diet versus High Sodium Diet on Blood Pressure, Renin, Aldosterone, Catecholamine, Cholesterol, and Triglyceride. Cochrane Database of Systematic Reviews, 11, CD004022.

[60] Cook, N.R., Cutler, J.A., Obarzanek, E., Buring, J.E., Rexrode, K.M., et al. (2007) Long-Term Effects of Dietary Sodium Reduction on Cardiovascular Disease Outcomes: Observational Follow-Up of the Trials of Hypertension Prevention (TOHP). BMJ, 334, 885-888. https://doi.org/10.1136/bmj.39147.604896.55

[61] Flynn, F.W. (1995) Applications of Taste Reactivity to the Study of the Neural-Hormonal Controls of Ingestive Behavior. Neuroscience \& Biobehavioral Reviews, 19, 109-120. https://doi.org/10.1016/0149-7634(94)00025-V

[62] Feeney, E., O’Brien, S., Scannell, A., Markey, A. and Gibney, E.R. (2011) Genetic Variation in Taste Perception: Does It Have a Role in Healthy Eating? Proceedings of the Nutrition Society, 70, 135-143. https://doi.org/10.1017/S0029665110003976

[63] Campbell, M.C. and Tishkoff, S.A. (2008) African Genetic Diversity: Implications for Human Demographic History, Modern Human Origins, and Complex Disease Mapping. Annual Review of Genomics and Human Genetics, 9, 403-433. https://doi.org/10.1146/annurev.genom.9.081307.164258

[64] Abrol, R., Tan, J., Hui, H., Goddard, W.A. and Pandol, S.J. (2015) Structural Basis for Bitter Taste Receptor Activation and It's Potential Role in Targeting Diabetes. Functional Foods in Health and Disease, 5, 117-125.

[65] Bando, M., Fujiwara, I., Imamura, Y., Takeuchi, Y., Hayami, E., et al. (2018) Lifestyle Habits Adjustment for Hypertension and Discontinuation of Antihypertensive Agents. Journal of Hypertension, 7, 248.

[66] Shimamoto, K., Ando, K., Fujita, T., Hasebe, N., Higaki, J., et al. (2014) The Task Force for the Management of Hypertension of the Japanese Society of Hypertension. Hypertension Research, 37, 253-390. https://doi.org/10.1038/hr.2014.20 